\title{
ET UPUBLICERET MARX-MANUSKRIPT OM VIDENSKAB OG KAPITAL
}

Den Marx-tekst, som vi her publicerer for første gang, ${ }^{1}$ stammer fra de forberedende arbejder til Kapitalen, som blev skrevet i 1863. ${ }^{2}$ Marx bestemmer her videnskabens rolle og placering i det kapitalistiske samfund.

Han viser, at naturkræfterne i og for sig intet koster, da de ikke er et produkt af det menneskelige arbejde. Men under kapitalistiske betingelser tilegner kapitalisterne - ejerne af produktionsmidlerne - sig disse gratis naturrigdomme ved hjælp af naturvidenskaberne. Således bliver videnskaberne som naturbeherskelsesmiddel under kapitalismen et middel til produktion af rigdom for den herskende klasse, altså et berigelsesmiddel for denne. Derfor fremhæver Marx overordentlig kraftigt, at videnskaben, menneskeheden teoretiske fremskridt, bliver udbyttet af kapitalismen: kapitalen, som ikke selv skaber videnskaben, udbytter denne og tilegner sig dens frugter.

Marx forklarer derefter, at hvis den kapitalistiske produktionsmåde på den ene side gør naturvidenskaberne til en faktor som tjener produktionsprocessen, så skaber udviklingen af produktionen på den anden side midler til den »teoretiske beherskelse af naturen $\ll$.

Overordentlig stor betydning må tillægges den tese som Marx fremsætter, ifølge hvilken videnskaben under kapitalismen er fremmed og fjendtlig over for arbejdet, at den underkaster sig dette, og at den bidrager til forstærkelse af kapitalens udbytning af arbejderklassen. På samme måde som udviklingen af produktionsbetingelserne og deres transformation til kapital hviler på adskillelsen mellem disse produktionsbetingelser og arbejderne, således hviler anvendelsen af videnskaben i den kapitalistiske produktionsproces på adskillelsen mellem de intellektuelle kræfter og arbejderne, dvs. på kvælningen af arbejdernes åndelige evner. Konklusionen i dette fragment begrunder endvidere yderligere hvorfor videnskaben under kapitalistiske betingelser gennemløber en bestemt udvikling.

Marx' konklusioner og teoretiske bemærkninger omkring videnskabens og teknikkens udvikling under kapitalismen er fuldt ud bekræftet af praksis. Under kapitalismens aktuelle betingelser betyder videnskabens og teknikkens

1. I tidsskriftet Kommunist, Moskva, 1958, nr. 8. På russisk. Oversat her (La Nouvelle Critique, nr. 100, november 1958 o.a.) efter fotokopi af den tyske original, som venligst er videregivet af Instituttet for marxisme-leninisme ved Centralkomiteen for SUKP, til hvem vi retter en hjertelig tak (Redaktionel note af La Nouvelle Critique).

2. Se især Kapitalen, fransk udgave, 1. Bind, 2. bog, s. 71ff. Editions Sociales, 1948. 
fremskridt altid - med et udtryk af Lenin - et fremskridt $\mathrm{i} »$ kunsten at få sveden til at springe frem $\ll$.

Instituttet for marxisme-leninisme ved SUKP's Centralkomité. ${ }^{3}$

3. Denne udgivelse er forberedt af Instituttets videnskabelige medarbejdere S. M. Grigorian og I. T. Kharitonov.

\section{KOMMENDE UDGIVELSER}

KURASJE udgiver i september 1976 følgende bøger:

\section{INFLATION OG KRISE}

En antologi med følgende bidrag:

- E. Altvater, J. Hoffmann, R. Künzel og W. Semmler: Inflation og kapitalvaloriseringens krise,

- Olaf E. Dombrowsky: Kritik af borgerlige inflationsteorier, og

- Paul Mattick: Den deflationære inflation. ca. 200 sider.

Christel Neusüss:

Imperialisme og det kapitalistiske verdensmarked ca. 250 sider.

Kurt Aagaard Nielsen:

Kvalifikationsstruktur og klassestruktur ca. 120 sider.

Rudi Schmiede:

\section{Akkumuler, Akkumuler! Det er Moses og profeterne!}

Grundlæggende problemer i den marxske akkumulations- og kriseteori.

ca. 200 sider.

Jindrich Zeleny:

Videnskabslogikken i Kapitalen

ca. 120 sider.

KURASJE vil den 1. september udsende et nyt katalog med oplysninger om priser og nøjagtige udgivelsesdatoer. Kataloget kan bestilles og vil blive tilsendt portofrit.

\section{KURASJE,}

Krystalgade 14/16, 1172 København K.

Giro: 7166044 


\section{VIDENSKAB OG KAPITAL ${ }^{4}$}

\section{KARL MARX}

Masseproduktionen - eller kooperation i stor målestok med anvendelse af maskineri - har sit udspring i, at naturkræfterne - vind, vand, damp, elektricitet - i stort omfang underlægges den umiddelbare produktionsproces: masseproduktionen transformerer disse til agenter for det samfundsmassige arbejde (i agrikulturen under dens prækapitalistiske former fremtræder det menneskelige arbejde snarere blot som hjælpemiddel for naturprocesserne, som det ikke er i stand til at kontrollere). I og for sig koster disse naturkræfter intet; de er ikke et produkt af menneskeligt arbejde. Men tilegnelsen af dem kan kun ske ved hjælp af maskinerne, som på deres side koster noget, i og med at de er produkt af et allerede udført arbejde. Som agenter for det samfundsmæssige arbejde bliver naturkræfterne således kun tilegnet ved hjælp af maskinerne og disses ejere.

Da disse natural-agenter intet koster, indlemmes de i arbejdsprocessen uden dermed at indlemmes i værdiproduktionsprocessen. De forhøjer arbejdets produktivkraft, men uden at forhøje produktets vardi, uden at føje noget til varernes værdi. Tværtimod, [værdien af] hver enkelt vare taget for sig formindskes, fordi massen af de varer, der produceres inden for den samme arbejdstid for$\emptyset$ ges, og fordi vaerdien af hver alikvot del af denne masse følgelig formindskes. I den udstrækning disse varer indgår i arbejdskraftens reproduktion vil værdien af denne arbejdskraft formindskes. Med andre ord: den for reproduktion af arbejdslønnen nødvendige tid vil være forkortet og merarbejdstiden forlænget. Det er i denne betydning at naturkræfterne ser sig tilegnet af kapitalen; det forholder sig altså ikke således, at disse forhøjer varernes værdi: tværtimod, de sænker disses [værdi], og de indgår i arbejdsprocessen uden at indgå i værdiproduktionsprocessen. Den udstrakte anvendelse af naturkræfterne er kun mulig, hvor maskineriet selv benyttes i stor målestok, og hvor der følgelig optræder en tilsvarende koncentration af arbejdere, og disse arbejderes kooperation er underkastet kapitalen.

Udnyttelsen af natural-agenterne - $\mathrm{i}$ et vist omfang deres inkorporering $\mathrm{i}$ kapitalen - falder sammen med videnskabens udvikling som autonom faktor i produktionsprocessen. Når produktionsprocessen bliver en anvendelse af videnskaben, bliver videnskaben omvendt en faktor i, eller så at sige en funktion af produktionsprocessen. Enhver opfindelse danner grundlag for en ny fremgangsmåde, en ny forædling af produktionsmetoderne. Det er først med den kapitalistiske produktionsmåde, at videnskaben stilles til rådighed for den

4. Redaktionel overskrift, Kurasje. 
umiddelbare produktionsproces, hvor produktionens udvikling imidlertid skaber midlet til teoretisk at beherske naturen. Først da får videnskaben til opgave at være et middel til produktion af rigdomme, et middel til berigelse.

Det er med denne produktionsmåde, at der for første gang opstår praktiske problemer, som kun kan løses videnskabeligt. Først fra dette tidspunkt nødvendigg ør selve produktionsprocessen, at der gøres eksperimenter og observationer på et niveau som tillader, som endog fordrer anvendelse af videnskaben, udnyttelse af videnskaben i menneskehedens teoretiske fremskridt. Kapitalen skaber ganske vist ikke videnskaben, men den udnytter den, idet den inkorporerer den i produktionsprocessen. Men samtidig sker der en adskillelse mellem videnskaben, forstået som videnskaben anvendt i produktionen, og det umiddelbare arbejde. I modsætning hertil er summen af viden (connaissances) begrænset på de tidligere stadier af produktionen, eksperimenterne er umiddelbart forbundet med selve arbejdet, og videnskaben kan ikke udvikle sig som en autonom kraft, der er adskilt fra arbejdet. Således omfatter videnskaben totalt set ikke mere end den receptmængde, som overføres af traditionen, og den udvikler sig kun ganske langsomt og i lille målestok (empirisk oplæring i hvert fags »hemmeligheder «). Ånden og hånden er endnu ikke adskilte.

Hr. Howell (en af fabriksinspektørerne) siger (Reports, etc. for the half year ending 31 st October 1856, s. 53): »Ifølge de største autoriteter inden for området skulle fabriksarbejdet vare en art lavere tvangsarbejde, som ikke fordrer anvendelse af [arbejdernes] åndelige evner « og han citerer med disse ord fabriksejerne selv: »Arbejderne burde altid holde sig for øje, at deres arbejde er en lavere form af det specialiserede arbejde, og at der ikke findes noget, som det er lettere at opnå færdighed i, eller bedre betalt $\mathrm{i}$ forhold til dets kvalitet. Ejheller findes der noget [arbejde], som en hurtig og billig læretid kan skaffe hurtigere og i større mængde... Fabriksejernes maskiner spiller $i$ realiteten en langt vigtigere rolle i produktionen end arbejdet og arbejderens kvalifikationer, hvor uddannelsen varer seks måneder, og som er inden for en hvilken som helst arbejders rækkevidde.« Side 17, The Masters Spinners and Manufacturers' Defence Fund, »Kommisionsrapport vedrørende oprettelsen og fordelingen af disse fonds ved Centralsammenslutningen af Spindemestre og Fabrikanter«.

Ordet fabrik, som det nævnes i interpretationsklausulen i Factory Act af 1844 (Victorias 7. regeringsår, artikel 15, § 73), er defineret således: »Ved ordet fabrik forstås bygninger og lokaliteter i eller inden for hvis rammer damp, vand eller en hvilken som helst anden mekanisk kraft anvendes til at bevæge eller igangsætte maskiner tjenende til udvindelse, forarbejdning eller færdiggørelse, eller til en hvilken som helst forarbejdningsproces af bomuld etc«. (Om genstanden, som her medvirker til at gøre fabrikken til en fabrik, er bomuld, uld, hestehår, silke, hør, hamp eller jute må naturligvis henføres til de lokale betingelser: dette vedrører ikke fabrikkens væsen). Når maskinerne 
her betegnes som »fabriksejerens maskiner«, når deres funktion assimileres til hans funktion i produktionsprocessen (»the business of production«), så forholder det sig på absolut samme måde med videnskaben, som er inkorporeret i disse maskiner, i fabrikationsprocesserne eller i de kemiske processer etc. Videnskaben træder op som en fremmed og fjendtlig magt over for arbejdet, en magt som underlagger sig arbejdet. Videnskabens anvendelse - på den ene side koncentrationen; på den anden transformationen af viden, af observationer, af de empirisk overførte faghemmeligheder til videnskab, til analyse af produktionsprocessen ved hjælp af anvendelse af naturvidenskaberne i den materielle produktionsproces - dens anvendelse hviler således på adskillelsen mellem lærdommens åndelige kræfter og den individuelle arbejders viden og dygtighed; på samme måde hviler koncentrationen og udviklingen af produktionsbetingelserne og disses transformation til kapital på den kendsgerning, at arbejderen er frarøvet og adskilt fra de selvsamme produktionsbetingelser. Fabriksarbejdet overlader ikke arbejderen meget andet end kendskab til begrænsede håndbevægelser. Med fabriksarbejdet ophæves oplæringens love; den kamp som staten etc. fører for at de unge arbejdere i det mindste lærer at læse og skrive, viser, at denne anvendelse af videnskaben i produktionsprocessen falder sammen med kvælningen af enhver åndelig udvikling i fabrikationsakten. Ganske vist uddanner man et lille antal kvalificerede arbejdere, men dette er for intet at regne i sammenligning med massen af »dekultiverede « arbejdere.

På den anden side står to ting klart.

Naturvidenskabernes egen udvikling (og de udgør grundlaget for enhver videnskab), såvel som al viden i relation til produktionen, foregår på basis af den kapitalistiske produktion, som for første gang skaber størstedelen af videnskabernes materielle midler til forskning, observation og eksperimentering. I den udstrækning videnskaben benyttes af kapitalen som berigelsesmiddel, hvorigennem den bliver et berigelsesmiddel for de, der udvikler den, i samme udstrækning vil videnskabsmændene indbyrdes konkurrere om at finde dens praktiske anvendelse. På den anden side bliver opfindelsen et selvstændigt erhverv. Det er under disse betingelser, at den videnskabelige faktor med den kapitalistiske produktion gennemløber en bevidst udvikling, at den anvendes og drives fremad i en målestok, som de tidligere epoker ikke havde nogen forestilling om.

Oversat af Mads Christoffersen 


\section{teori og klassekamp}

TEORI \& KLASSEKAMP er et nyt märxistisk tidsskrift, som udgives af Engelsk Fagfront ved Københavns Universitet.

Formålet med TEORI \& KLASSEKAMP er at bidrage til at holde liv i den marxske videnskabs revolutionære kritikkraft på et tidspunkt, hvor den ikke er materielt forankret i arbejderklassen. Dette gøres ikke - som i en fremherskende tendens på venstrefløjen - ved at bannerføre 'ned med teorien, op med praksis'. Eftersom venstrefløjen domineres af mellemlag, bliver denne praksis nemlig uvægerligt vores lagsspecifikke praksis - ikke arbejderklassens. Når arbejderklassen kæmper, da - og først da - er de venstreorienteredes opgave politisk givet.

TEORI \& KLASSEKAMP $\mathbf{1 - 2}$ indeholder:

Erik Wienberg: INTRODUCERENDE BEMAERKNINGER TIL MELLEMLAGSPROBLEMATIKKEN

Gerhard Armanski: STATSLIGE LØNARBEJDERE I KAPITALISMEN

Randi Hedetoft \& Nanna Hvidt: OM KVINDEBEVÆEGELSEN I MELLEMLAGENE

Gerhard Vinnai: SOCIALISATION SOM PRODUKTION AF VAREN ARBEJDSKRAFT

UIf Hedetoft: REPRODUKTION OG BEVIDSTHEDSDANNELSE I ARBEJDERFAMILIEN

Dann Simonsen \& Jeff Snider: ANMELDELSE AF 'SOCIALISTISK POLITIK' NR. 1

TEORI \& KLASSEKAMP bestræber sig - positivt bestemt - på at oparbejde det arbejderstandpunkt, som kritikken af den politiske økonomi indeholder, helt frem mod kapitalakkumulationens historisk-konkrete former. Eller med andre ord: at fastholde kapitallogikkens konstituerende betydning for klassedynamikken. Vi sympatiserer med arbejdet med en reorientering af marxismen mod empirien, men vel at mærke: for så vidt dette sker uden opgivelse af det marxske fremstillingsideal. Artikler i de kommende numre vil ligge inden for dette spektrum: krise-, statsog klasseanalyse.

TEORI \& KLASSEKAMP koster i løssalg (som besørges af KURASJE) pr. enkeltnummer $12,50 \mathrm{kr}$. og pr. dobbeltnummer 25,00 kr. ABONNEMENT for numrene 1-4 tegne ved indbetaling af $37,50 \mathrm{kr}$. til:

\section{TEORI \& KLASSEKAMP}

Thorsagde 13, IV. tv. 2200 N. GIRO 7289898

\section{BENYT VEDLAGTE GIROKORT!!!}

"At kapitallogikken i sin mere platte udgave dog langtfra er afgået ved en stille død, vidner f.eks. Engelsk Fagfronts nye tidsskrift 'Teori og Klassekamp' særdels overbevisende om«.

SOCIALISTISK POLITIK nr. 3 Lisbeth Gunlund Jensen \& Just Justesen 